Reviu Akuntansi dan Bisnis Indonesia, Vol. 5 No. 1, Hlm: 104-111, Juli 2021

Website: http://journal.umy.ac.id/index.php/rab

\title{
Pengaruh Loan to Deposit Ratio, Net Profit Margin, dan Dept to Equity Ratio terhadap Profitabilitas (Studi kasus pada Bank Umum Syariah yang terdaftar di Bursa Efek Indonesia periode tahun 2015-2019)
}

Yossi Margarita*; Nur Kholis

Program Studi Akuntansi, STIE Surakarta

\begin{tabular}{l}
\hline I N F O A R T I K E L \\
\hline Kata Kunci: \\
Loan to Deposit Ratio \\
(LDR); Net Profit Margin \\
(NPM); Dept to Equity \\
Ratio (DER); Profitabilitas \\
Jenis Artikel: \\
Penelitian Empiris \\
Korespondensi: \\
margarethayossi3@gmail.com \\
Proses Artikel: \\
Diterima 1 April 2021 \\
Review 29 April 2021 \\
Review 4 Mei 2021 \\
Revisi 26 Juni 2021 \\
Diterbitkan 1 Juli 2021 \\
Sitasi: \\
Margarita, Y., \& Kholis, N. \\
(2021). Pengaruh Loan to \\
Deposit Ratio, Net Profit \\
Margin, dan Dept to Equity \\
Ratio terhadap \\
Profitabilitas (Studi kasus \\
pada Bank Umum Syariah \\
yang terdaftar di Bursa \\
Efek Indonesia periode \\
tahun 2015-2019). Reviu \\
Akuntansi dan Bisnis \\
Indonesia, 5(1), 104-111. \\
Link Artikel: \\
10.18196/rabin.v5i1.11409 \\
\hline \\
\end{tabular}

ABSTRAK

\section{Latar Belakang:}

Bank bisa dikatakan sebagai tempat transaksi yang berhubungan dengan keuangan misalnya untuk melakukan investasi, pengiriman uang dan tempat mengamankan uang. Otoritas Jasa Keuangan mencatat pertumbuhan aset keuangan syariah di Indonesia terus melaju. Per Januari 2021, total aset keuangan syariah Indonesia (tidak termasuk saham syariah) mencapai Rp1.823,13 triliun. Jumlah tersebut tumbuh 24,54\% secara year on year.

Tujuan:

Tujuan penelitian ini untuk menguji secara empiris dan menganalisis pengaruh Loan to Deposit Ratio (LDR), Net Profit Margin (NPM) dan Dept to Equity Ratio (DER) terhadap profitabilitas pada Bank Umum Syariah di Indonesia.

\section{Metode Penelitian}

Sampel yang digunakan Bank Umum Syariah di Indonesia yaitu Laporan Keuangan Perusahaan Perbankan umum syariah yang terdaftar di BEI periode tahun 2015-2019. Sumber data tersebut diunduh dari web resmi IDX. Menggunakan persamaan regresi linear berganda dan program SPSS 26.

\section{Keterbatasan Penelitian :}

Keterbatasan penelitian ini variabel bebas yang digunakan hanya 3 variabel yaitu (LDR) Loan to Deposit Ratio, (NPM) Net Profit Margin dan (DER) Dept to Equity Ratio. Jumlah sampel 33 selama pengamatan 5 tahun.

Keaslian / Novetly Penelitian :

Penelitian yang terkait dengan pengaruh NPM, LDR dan DER terhadap profitabilitas terus mengalami perkembangan. Penelitian ini dapat memberikan informasi yang baru tentang perusahaan Perbankan Syariah Indonesia, sejauh mana profitabilitas perusahaan tersebut terukur dengan baik atau tidak.

(C) 2021 RAB. Published by Universitas Muhammadiyah Yogyakarta DOI: 10.18196/rabin.v5i1.11409

\section{PENDAHULUAN}

Bank merupakan lembaga keuangan yang kegiatan utamanya menghimpun dana dari masyarakat dan menyalurkan kembali kepada masyarakat. Di Indonesia yang mayoritas masyarakatnya beragama Islam melihat bank konvensional masih dipandang kurang. Sehingga 
minat masyarakat dalam penggunaan layanan perbankan syariah tinggi. Bank merupakan mitra dalam rangka memenuhi kebutuhan keuangan. Bank bisa dikatakan sebagai tempat transaksi yang berhubungan dengan keuangan misalnya untuk melakukan investasi, pengiriman uang dan tempat mengamankan uang. Dengan demikian pertumbuhan aset mengalami peningkatan dari tahun ke tahun. Berdasarkan Bisnis.com, Jakarta. Otoritas Jasa Keuangan mencatat pertumbuhan aset keuangan syariah di Indonesia terus melaju. Per Januari 2021, total aset keuangan syariah Indonesia (tidak termasuk saham syariah) mencapai Rp1.823,13 triliun. Jumlah tersebut tumbuh 24,54\% secara year on year (yoy). Pertumbuhan pada awal tahun itu melampaui pertumbuhan aset keuangan syariah secara tahunan dalam tiga tahun terakhir. Total aset keuangan syariah tumbuh $14,15 \%$ pada 2018 , kemudian $13,84 \%$ pada 2019 , dan $22,79 \%$ pada 2020 . Dari fenomena yang terjadi hal tersebut menggambarkan begitu tingginya kepercayaan masyarakat terhadap perbankan syariah sehingga hal tersebut sangat mempengaruhi Profitabilitas Bank Umum Syariah di Indonesia.

Perusahaan yang perolehan laba bersihnya lebih besar dari pendapatan operasionalnya maka profitabilitas perusahaan dapat dikatakan bagus. Hal ini berbanding lurus dengan kemampuan perusahaan dalam pengembalian kewajiban atau hutang perusahaan terhadap pihak lain. Rendahnya hutang yang dimiliki maka menunjukkan peningkatan profitabilitas perusahaan. Pencapaian laba perusahaan sangat dipengaruhi Dept to Equity Ratio (DER). Kecilnya Dept to Equity Ratio/DER mencerminkan pertumbuhan profit sangat baik. Dengan demikian pihak luar akan menaruh kepercayaan yang tinggi terhadap perusahaan. Bank yang sehat pasti menghasilkan kenaikan laba yang besar sehingga mampu menunjang aktivitasnya dalam melakukan pembiayaan kredit serta mengendalikan simpanan dan pinjamannya kepada masyarakat ataupun pihak lain. Hal ini dapat ditunjukkan dengan besarnya Loan to Deposit Ratio (LDR).

Menurut (Harun 2016) menyatakan bahwa Loan to Deposit Ratio berpengaruh signifikan terhadap Return on Asset. Hasil uji hipotesis parsial, variabel bebas Net Profit Margin memiliki hubungan positif dan berpengaruh secara parsial terhadap varaibel terikat Return on Asset, dan menurut penelitian yang dilakukan oleh (Apriliani \& Ibnu, 2018) Dept to Equity Ratio berpengaruh negatif secara signifikan terhadap Return on Asset.

Dengan uraian, maka peneliti terdorong untuk meneliti apakah secara signifikan Loan to Deposit Ratio (LDR), Net Profit Margin (NPM), dan Dept to Equity Ratio (DER) memiliki pengaruh terhadap profitabilitas pada bank umum syariah. Tujuan dari penelitian ini yaitu menguji secara empiris dan menganalisis pengaruh Loan to Deposit Ratio (LDR), Net Profit Margin (NPM),dan Dept to Equity Ratio (DER) terhadap profitabilitas bank umum syariah pada periode 2015-2019.

\section{TINJAUAN LITERATUR DAN PERUMUSAN HIPOTESIS}

\section{Teori Signal (Signalling Theory)}

Teori yang menjelaskan perusahaan memberikan sinyal terhadap koperasi keuangan menurut teori signal Brigham, Houston, dan Yulianto (2006). Signal merupakan tindakan yang diperoleh perusahaan guna memberikan petunjuk investor mengenai cara manajemen melihat prospek perusahaan. Perusahaan memberikan sinyal berdasarkan tindakan dan komunikasi. Berdasarkan hal tersebut perusahaan mengambil sinyal tersebut untuk pihak yang dipengaruhi secara langsung keputusan dan strategi perusahaan. Bank sebagai tempat transaksi yang berhubungan dengan keuangan seperti halnya investasi, pengiriman uang serta tempat mengamankan uang. Hal-hal berikut berdampak pada kemajuan suatu bank. Indikator semakin banyak investor masuk maka semakin bagus prospek bank itu sendiri.

\section{Loan to Deposit Ratio (LDR)}

Loan to Deposit Ratio (LDR) adalah untuk menghitung jumlah kredit yang diberikan dibandingkan jumlah dana masyarakat dan modal sendiri yang digunakan, menurut (Putra, Lubis, \& Simanjuntak, 2021). Kecilnya Loan to Deposit Ratio (LDR) suatu bank mempengaruhi kinerja bank tersebut dan kinerja bank yang baik akan meningkatkan kepercayaan masyarakat. Loan to 
Deposit Ratio (LDR) adalah gambaran mengukur komposisi total kredit yang akan diberikan dengan jumlah dana masyarakat serta modal mereka sendiri. Semakin tinggi ratio yang digunakan, maka semakin rendah likuiditas bank yang bersangkutan untuk kemungkinan suatu bank dalam kondisi yang bermasalah akan semakin besar pula. Kredit yang dapat diberikan tidak termasuk kredit kepada bank lain sedangkan untuk dana pihak ketiga ialah tabungan, simpanan berjangka dan giro.

\section{Net Profit Margin (NPM)}

Menurut Safitri dan Mukaram (2018) NPM merupakan ukuran keuntungan dengan membandingkan antara laba setelah bunga dan pajak dibandingkan dengan penjualan. NPM merupakan rasio yang digunakan untuk mengukur seluruh efektivitas dalam menghasilkan penjualan dan biaya pengendalian (Bionda \& Mahdar, 2017). NPM merupakan cerminan atas kemampuan suatu perusahaan untuk memperoleh laba bersih pada tiap penjualannya (Ginting, 2019). Rasio berikut menunjukkan besarnya persentase keuntungan neto yang didapat dari setiap penjualan. Semakin besar nilai rasio ini, maka dianggap semakin bagus tingkat kemampuan perusahaan untuk mencapai laba yang tinggi. Semakin tinggi nilai dari NPM maka mengindikasikan semakin baik dari profitabilitas perusahaan. Hubungan antara keuntungan bersih setelah pajak dan penjualan neto dapat menunjukkan kemampuan suatu manajemen dalam menjalankan perusahaan cukup berhasil untuk dapat menyisakan laba.

\section{Dept to Equity Ratio (DER)}

Memberikan gambaran mengenai struktur modal yang dimiliki perusahaan, sehingga dapat dilihat tingkat risiko tidak tertagihnya satu utang oleh para investor. Semakin besar nilai Dept to Equity Ratio (DER) semakin besar jumlah aktiva yang dibiayai oleh pemilik perusahaan, dan semakin kecil nilai Dept to Equity Ratio (DER) berarti semakin kecil jumlah aktiva yang dibiayai oleh pemilik perusahaan. DER merupakan rasio yang digunakan untuk menilai suatu perusahaan memiliki kemampuan dalam menutupi hutangnya dengan modal sendiri (Agustina \& Mulyadi, 2019). Hal ini menunjukkan semakin besar nilai dari DER, maka akan semakin besar pula aktiva dari bank yang dibiayai oleh hutang, apabila hutang tersebut makin besar maka dapat berisiko pada bank (Apriliani \& Ibnu, 2018).

\section{Profitabilitas}

Profitabilitas adalah rasio yang digunakan dalam mencari keuntungan perusahaan pada periode tertentu. Menurut Widiyanti (2019) Pengaruh Return on Asset (ROA) terhadap prediksi laba perusahaan yaitu semakin tinggi nilai Return on Asset (ROA) semakin tinggi pula laba yang dihasilkan, dengan itu Return on Asset (ROA) dijadikan alat untuk memprediksi laba. Return on Asset (ROA) rasio keuangan perusahaan yang berhubungan dengan profitabilitas unuk mengukur kemampuan perusahaan menghasilkan laba pada tingkat pendapatan, aset dan modal saham tertentu dalam (Widiyanti, 2019).

Profitabilitas merupakan kemampuan suatu perusahaan untuk memperoleh laba dalam kaitannya dengan penjualan, total asset, maupun modal sendiri, sehingga investor akan memperhatikan analisis profitabilitas (Afkar, 2017). Profitabilitas merupakan hasil dari kebijakan yang diambil oleh manajemen dalam mengukur seberapa besar tingkat keuntungan yang menunjukan semakin baik manajemen dalam mengelola perusahaan (Kusumastuti \& Alam, 2019). Jika Rasio Profitabilitas (ROA) bank syariah menunjukkan kinerja yang baik, maka lembaga yang berdasarkan prinsip syariah akan berperan dan memberikan kontribusi lebih untuk kesejahteraan masyarakat (Nugroho, Badawi, \& Hidayah. 2019).

Unsur yang mempengaruhi profitabilitas antara lain, besarnya perusahaan, tingkat penjualan, dan unsur perusahaan. Maka diharapkan unsur yang terkait dengan profitabilitas tersebut dilakukan dengan maksimal agar mencapai target yang diinginkan, sebab profitabilitas merupakan bagian penting yang menyangkut kinerja suatu perusahaan. 


\section{Pengaruh Loan to Deposit Ratio (LDR) dan profitabilitas}

Putra dkk (2021) menyatakan Loan to Deposit Ratio secara parsial berpengaruh positif dan signifikan terhadap pertumbuhan laba pada perbankan yang terdaftar di Bursa Efek Indonesia. Loan to Deposit Ratio (LDR) digunakan untuk mengukur kemampuan bank mampu membayar utang dan deposannya serta memenuhi permintaan kredit yang diajukan. Apabila bank tidak mampu menyalurkan kredit akan menyebabkan kerugian pada bank (Safitri \& Mukaram, 2018). LDR/Loan to Deposit Ratio berpengaruh signifikan terhadap ROA/Return on Asset (Harun, 2016).

\section{$\boldsymbol{H}_{\text {: }}$ Loan to Deposit Ratio (LDR) berpengaruh signifikan terhadap profitabilitas}

\section{Pengaruh Hubungan Net Profit Margin dan profitabilitas}

Semakin besar Net Profit Margin (NPM) pada suatu perusahaan akan meningkatkan penjualan perusahaan dan kinerja perusahaan pun akan semakin produktif, sehingga akan meningkatkan kepercayaan investor untuk menambah modalnya pada perusahaan. Hasil uji hipotesis parsial, variabel bebas NPM memiliki hubungan positif dan berpengaruh secara parsial terhadap variabel terikat ROA (Murhpy, 2019).

\section{$\boldsymbol{H}_{2}$ : Net Profit Margin berpengaruh signifikan terhadap profitabilitas}

\section{Pengaruh Hubungan Debt to Equity Ratio dan profitabilitas}

Tingginya nilai Dept to Equity Ratio (DER) pada suatu perusahaan akan membuat semakin tinggi pula jumlah aktiva yang dibiayai oleh pemilik perusahaan dan apabila semakin kecil nilai Dept to Equity Ratio (DER) berarti semakin kecil jumlah aktiva yang dibiayai oleh pemilik perusahaan. Menurut penelitian yang dilakukan oleh (Apriliani \& Ibnu, 2018) DER berpengaruh negatif secara signifikan terhadap ROA.

\section{$\boldsymbol{H}_{3}$ : Debt to Equity Ratio berpengaruh signifikan terhadap profitabilitas}

\section{METODE PENELITIAN}

Dalam penelitian ini data yang digunakan adalah data kuantitatif. Data diperoleh dari Laporan Keuangan Perusahaan Perbankan umum syariah yang terdaftar di BEI periode tahun 2015-2019. Sumber data tersebut diunduh dari web resmi IDX yaitu www.idx.co.id. Jumlah sampel diperoleh sebanyak 33 dari bank umum syariah di Indonesia selama 5 tahun. Data-data yang berupa angkaangka yang dapat digunakan sebagai dasar pengukuran data kuantitatif. Pengukuran variabel penelitian ini dalam memperjelas obyek yang diteliti maka peneliti menggunakan alat ukur sebagai berikut:

LDR $=\frac{\text { Laba Sebelum Pajak }}{\text { Total Aseet }} \times 100 \%$
NPM $=\frac{\text { Laba bersih setelah Pajak Perusahaan }}{\text { Penjualan Perusahaan }} \times 100 \%$



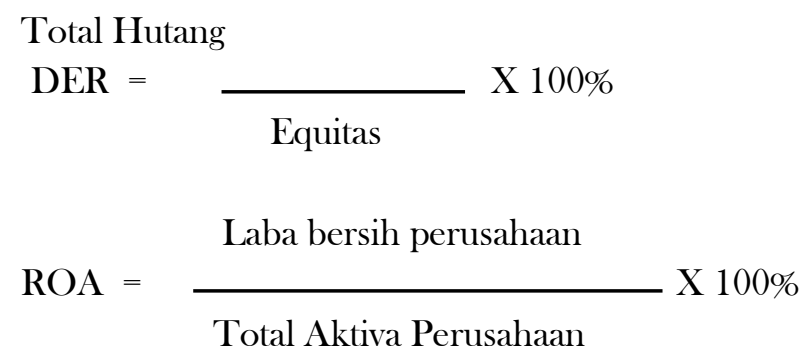

Analisis yang digunakan dalam penelitian ini menggunakan analisis regresi berganda dan menggunakan program SPSS 26. Dalam model analisis regresi berganda akan diuji secara parsial (Uji t). Hasil uji t dilihat dari kolom sig dengan kriteria bilamana nilai signifikan lebih banyak dari 0,05 itu berarti tidak berpengaruh signifikan dan bilamana nilai sig lebih sedikit dari 0,05 berarti terjadi pengaruh signifikan (Nurtantiono, 2020).

Ada tidaknya ikatan antara variabel yang digunakan dalam penelitian sangat penting untuk mengetahui dan membuktikan dalam percobaan $\mathrm{Uji} F$, sebagai pedoman angka sig nya lebih sedikit dari 0,05 itu berarti sangat penting (Nurtantiono, 2020). Uji Koefisien determinasi dalam regresi linear berganda digunakan untuk mengetahui persentase pengaruh variabel independen secara bersama-sama terhadap variabel dependen.

\section{HASIL DAN PEMBAHASAN}

\section{Uji Asumsi Klasik}

1. Uji Normalitas

Berdasarkan uji normalitas dapat kita lihat hasilnya bahwa nilai Asymp. Sig. (2-tailed) sebesar 0,190c yang berarti lebih besar dari 0,05 maka data residual yang digunakan dalam penelitian ini berdistribusi normal.

2. Uji Multikolinearitas

Menurut Uji Multikolinearitas hasilnya menunjukkan nilai Tolerance lebih besar sama dengan 0,10 dan nilai VIF lebih kecil dari 10 pada setiap variabelnya. $\mathrm{LDR}$ nilai $\mathrm{TOL}=0,742$ dan nilai VIF $=1,348$, NPM nilai $\mathrm{TOL}=0,647$ dan nilai $\mathrm{VIF}=1,545$, DER nilai $\mathrm{TOL}=0,848$ dan nilai $\mathrm{VIF}=$ 1,179. Maka dapat disimpulkan bahwa variabel Loan to Deposit Ratio (LDR), Net Profit Margin (NPM), dan Dept to Equity Ratio (DER) terhindar dari Multikolinearitas.

\section{Uji Heteroskedastisitas}

Berdasarkan Uji Heteroskedastisitas dapat kita lihat hasilnya bahwa nilai sig. setiap variabel nilainnya lebih besar sama dengan 0,005. X1 (LDR ) $=0,097$ X2 (NPM) $=0,306$ X3(DER) $=0,057$. Maka dapat disimpulkan bahwa variabel Loan to Deposit Ratio (LDR), Net Profit Margin (NPM), dan Dept to Equity Ratio (DER) tidak ada heteroskedastisitas.

\section{Uji Autokorelasi}

Menurut Uji Autokorelasi hasilnya menunjukkan nilai dari Durbin-Watson sebesar 1,662, nilai $\mathrm{dU}=1,6511$ dan 4-dU $=2,3489$. Sedangkan hasil dari Durbin-Watson berada diantara nilai dU sampai dengan 4-dU maka dapat disimpulkan Loan to Deposit Ratio (LDR), Net Profit Margin (NPM), dan Dept to Equity Ratio (DER) dalam penelitian ini tidak terdapat autokorelasi.

\section{Uji Hipotesis}

Analisis Regresi Berganda

Ringkasan Hasil Analisis regresi linear berganda adalah sebagai berikut: 
Tabel 1 Hasil Uji Regresi Linear Berganda

\begin{tabular}{llcrl}
\hline \multicolumn{1}{c}{ Variabel } & Beta & t hitung & Sig. & Kesimpulan \\
\hline Loan to Deposit Ratio (LDR) (X1) & 0,129 & 2,372 & 0,025 & Signifikan \\
Net Profit Margin (NPM (X2) & 0,003 & 0,251 & 0,804 & Tidak Signifikan \\
Dept to Equity Ratio (DER) (X3) & 0,003 & 3,515 & 0,001 & Signifikan \\
Uji F & 0,002 & & & \\
Adjusted R Square & 0,331 & & & \\
Profitabilitas (Y) & Variabel Dependen & & \\
\hline
\end{tabular}

Persamaan regresi linear berganda yang kita dapatkan dari hasil analisis, yaitu:

$$
\mathrm{Y}=0,000+0,129 \mathrm{X} 1+0,003 \mathrm{X} 2+0,003 \mathrm{X} 3
$$

Arti dari persamaan regresi linear berganda tersebut nilai konstanta sebesar $=0,000$. Jika variabel Loan to Deposit Ratio (LDR), Net Profit Margin (NPM), dan Dept to Equity Ratio (DER) nilai konstantannya tidak berubah maka nilai dari profitabilitas akan naik sebesar 0,000 . Nilai koefisien regresi variabel X1 (LDR) yaitu sebesar $=0,129$, jika LDR mengalami kenaikan maka berarti profitabilitas mengalami kenaikan sebesar 0,129, nilai koefisien regresi variabel X2 (NPM) sebesar $=0,003$, jika NPM mengalami kenaikan maka berarti profitabilitas mengalami kenaikan sebesar 0,003 dan nilai Nilai koefisien regresi variabel X3 (DER) sebesar $=0,003$, jika nilai DER mengalami kenaikan maka berarti profitabilitas mengalami kenaikan sebesar 0,003.

\section{Uji Parsial (Uji t)}

Pengaruh Loan to Deposit Ratio (LDR) terhadap Profitabilitas

Berdasarkan uji regresi maka diperoleh nilai t-hitung sebesar 2,372 dengan koefisien 0,129 dengan nilai signifikansi sebesar 0,025 yang dapat disimpulkan bahwa Loan to Deposit Ratio (LDR) berpengaruh positif dan signifikan terhadap Profitabilitas. Hal ini menunjukkan bahwa Loan to Deposit Ratio (LDR) semakin meningkat maka Profitabilitas juga akan meningkat. $\mathrm{H}_{1}$ Diterima.

Pengaruh Net Profit Margin (NPM) terhadap Profitabilitas

Berdasarkan uji regresi maka diperoleh nilai t-hitung sebesar 0,251dengan koefisien 0,003 dengan nilai signifikansi sebesar 0,804 yang dapat disimpulkan bahwa Net Profit Margin (NPM) tidak berpengaruh positif dan signifikan terhadap Profitabilitas. Hal ini menunjukkan bahwa Net Profit Margin (NPM) semakin meningkat maka Profitabilitas akan turun. $\mathrm{H}_{2}$ Ditolak.

Pengaruh Dept to Equity Ratio (DER) terhadap Profitabilitas

Berdasarkan uji regresi maka diperoleh nilai t-hitung sebesar 3,515 dengan koefisien 0,003 dengan nilai signifikansi sebesar 0,001 yang dapat disimpulkan bahwa Dept to Equity Ratio (DER) berpengaruh positif dan signifikan terhadap Profitabilitas. Hal ini menunjukkan bahwa Dept to Equity Ratio (DER) semakin meningkat maka Profitabilitas juga akan meningkat. $\mathrm{H}_{3}$ Diterima.

\section{Uji Simultan (Uji F)}

Tabel 2 Hasil Uji F

\begin{tabular}{ccccc}
\hline & Model & F & Sig. & Keterangan \\
\hline 1 & Regression & 6,271 &, $002^{\mathrm{b}}$ & Berpengaruh \\
\hline
\end{tabular}

Berdasarkan uji f kita dapat menyimpulkan bahwa nilai sig. variabel (LDR) Loan to Deposit Ratio, (NPM) Net Profit Margin dan (DER) Dept to Equity Ratio berpengaruh signifikan secara simultan. 


\section{Koefisien Determinasi (R2)}

Tabel 3 Hasil Uji Koefisien Determinasi

\begin{tabular}{ccc}
\hline Model & Adjusted R Square & Keterangan \\
\hline 1 & 0,331 & Berpengaruh \\
\hline
\end{tabular}

Menurut hasil Uji Determinasi bahwa nilai Loan to Deposit Ratio (LDR), Net Profit Margin (NPM), dan Dept to Equity Ratio (DER), memiliki kontribusi terhadap pertumbuhan laba sebesar 0,331 (33,1\%). Selebihnya sebesar 66,9\% dipengaruhi oleh faktor-faktor lain di luar penelitian ini. Pengaruh Loan to Deposit Ratio (LDR) terhadap profitabilitas.

Dari hasil uji t bahwa variabel Loan to Deposit Ratio (LDR) nilai sig. nya 0,025 berarti $\mathrm{H}_{\mathrm{i}}$ diterima, karena nilai sig. nya lebih kecil dari 0,05. Jika likuiditas bank yang bersangkutan itu kecil, maka semakin tinggi resikonya karena dana untuk membiayai kredit jumlahnya semakin besar. Penelitian ini sejalan dengan (Harun, 2016) Loan to Deposit Ratio (LDR) berpengaruh signifikan positif terhadap Return on Asset (ROA).

Pengaruh Net Profit Margin (NPM) terhadap profitabilitas

Dari hasil uji t bahwa variabel Net Profit Margin (NPM) nilai sig. nya 0,804 berarti $\mathrm{H}_{1}$ tidak diterima, karena nilai sig. nya lebih besar dari 0,05. Jika laba bersih dan penjualan perusahaan semakin besar maka kinerja perusahaan semakin produktif, sehingga akan meningkatkan kepercayaan investor untuk menanamkan modalnya pada perusahaan tersebut. Jika perusahaan tersebut mampu menghasilkan pertumbuhan laba yang tinggi tentunya sangat berpengaruh signifikan terhadap kinerja suatu entitas usaha dalam hal produktivitas. Dalam penelitian ini Net Profit Margin (NPM), menghasilkan nilai koefisiensi 0,251 (25,1\%), sedangkan nilai mean 14,1\% jadi nilai tersebut dianggap relatif kecil yang artinya adalah nilai laba bersih yang dicapai perusahaan terhadap penjualannya masih terbilang rendah belum memenuhi standar, sehingga hipotesisnya tidak bisa didukung. Hal ini relevan dengan penelitian Bionda dan Mahdar (2017) menyatakan bahwa Net Profit Margin tidak berpengaruh positif dan signifikan terhadap pertumbuhan laba perusahaan.

Pengaruh Dept to Equity Ratio (DER) terhadap profitabilitas

Dari hasil uji t bahwa variabel Dept to Equity Ratio (DER) nilai sig. nya 0,001 berarti $\mathrm{H}_{1}$ diterima, karena nilai sig. nya lebih kecil dari 0,05. Semakin tinggi Dept to Equity Ratio (DER) menunjukkan semakin besar laba perusahaan terhadap pihak luar, secara otomatis sangat memungkinkan menurunkan kinerja perusahaan dikarenakan tingkat ketergantungan dengan pihak luar semakin tinggi. Menurut penelitian yang dilakukan oleh (Apriliani \& Ibnu, 2018) Dept to Equity Ratio (DER) berpengaruh secara signifikan terhadap Return on Asset (ROA).

\section{KESIMPULAN}

Berdasarkan hasil penelitian serta pembahasan maka dapat diperoleh kesimpulan bahwa Loan to Deposit Ratio (LDR) dan Dept to Equity Ratio (DER) berpengaruh signifikan terhadap Profitabilitas, sedangkan Net Profit Margin (NPM) tidak berpengaruh signifikan terhadap Profitabilitas pada Bank Umum Syariah yang terdaftar diBEI tahun 2015-2019.

Hasil penelitian ini memberikan implikasi bahwa untuk meningkatkan profitabilitas pada bank umum syariah adalah Loan to Deposit Ratio (LDR) dan Dept to Equity Ratio (DER). Ini menunjukkan bahwa bank harus memiliki likuiditas yang kecil dari modal,sehingga semakin tinggi resikonya karena dana untuk membiayai kredit jumlahnya semakin besar yang akan mempengaruhi jumlah keuntungan bank.

Keterbatasan penelitian ini variabel bebas yang digunakan hanya 3 variabel yaitu (LDR) Loan to Deposit Ratio, (NPM) Net Profit Margin dan (DER) Dept to Equity Ratio. Jumlah sampel 33 selama pengamatan 5 tahun. Saran untuk peneliti berikutnya diharapkan untuk bisa menambah 
jumlah sampel dari variabel bebas. Jumlah sampel hendaknya ditambah lagi agar sampel tidak terbatas hanya 33 sehingga menghasilkan hasil penelitian yang maksimal. Saran untuk Bank Umum Syariah supaya meningkatkan kinerja dalam menghasilkan profit dan saran untuk investor diharapkan lebih memperhatikan perusahaan yang akan diinvestasi dalam kemampuannya untuk menghasilkan profit. Sehingga investor dapat memprediksi profit yang akan diterima.

\section{DAFTAR PUSTAKA}

Afkar, T. (2017). Influence analysis of mudharabah financing and qardh financing to the profitability of Islamic banking in Indonesia. AJIE-Asian Journal of Innovation and Entrepreneurship 2(03), 34-51. Diakses dari https://journal.uii.ac.id/ajie/article/view/8355

Agustina, D. N., \& Mulyadi, M. (2019). Pengaruh debt to equity ratio, total asset turn over, current ratio, dan net profit margin terhadap pertumbuhan laba pada perusahaan manufaktur di Bursa Efek Indonesia. ADVANCE-Journal of Accounting, 6(1):106-15. Diakses dari https://ejournal.stie-aub.ac.id/index.php/advance/article/view/546

Apriliani, L., \& Ibnu, A.R. (2018). Analisis struktur modal Bank Syariah Mandiri terhadap tingkat profitability periode 2013-2018. Jurnal Nisbah 5(2), 116-26. Diakses dari https://ojs.unida.ac.id/JN/article/view/1836

Bionda, A.R., \& Mahdar, N.M. (2017). Pengaruh Gross Profit Margin, Net Profit Margin, Return on Asset, dan Return on Equity terhadap Pertumbuhan Laba pada Perusahaan Manufaktur di Bursa Efek Indonesia. Kalbis Socio Jurnal Bisnis dan Komunikasi, 1(4), 10-16.

Brigham, E. F., Houston, J. F., \& Yulianto, A. A. (2006). Dasar-Dasar Manajemen Keuangan : Fundamentals of Financial Management (Buku 2). Jakarta :Salemba Empat.

Ginting, S. (2019). Analisis pengaruh CAR, BOPO, NPM dan LDR terhadap pertumbuhan laba dengan suku bunga sebagai variabel moderasi pada perusahaan perbankan yang terdaftar di Bursa Efek Indonesia Periode 2013-2016. Jurnal Wira Ekonomi Mikroskil 9(1), 97-106. Diakses dari https://www.mikroskil.ac.id/ejurnal/index.php/jwem/article/view/616

Harun, U. (2016). Pengaruh ratio-ratio keuangan CAR, LDR, NIM, BOPO, NPL terhadap ROA. Jurnal Riset Bisnis dan Manajemen, 4(1), 67-82. Diakses dari https://ejournal.unsrat.ac.id/index.php/jrbm/article/view/12352

Kusumastuti, W. I., \& Alam, A. (2019). Analysis of impact of CAR, NPF, BOPO on profitability of Islamic banks (Year 2015-2017). Journal of Islamic Economic Laws, 2(1), 30-59. https://doi.org/10.23917/jisel.v2i1.6370

Murhpy, C.B. (2019). Net Profit Margin. Investopedia. Diakses dari https://www.investopedia.com/terms/n/net_margin.asp

Nugroho, L., Badawi, A., \& Hidayah, N. (2019). Indonesia Islamic bank profitability 2010-2017. Shirkah: Journal of Economics and Business, 4(1). https://doi.org/10.22515/shirkah.v4i1.240

Nurtantiono, A. (2020). Analisis regresi kasus dan analisis dengan SPSS. Surakarta: Sekolah Tinggi Ilmu Ekonomi Surakarta.

Putra, A.F., Lubis, M.A., \& Simanjuntak, S. (2021). Pengaruh Capital Adequacy Ratio, Return on Assets, biaya operasional terhadap pendapatan operasional, Loan to Deposits Ratio terhadap pertumbuhan laba (Studi kasus pada perbankan di Bursa Efek Indonesia periode 2016-2019). Journal of Management Analytical and Solution, 1(1). Diakses dari https://talenta.usu.ac.id/jomas/article/view/5242

Safitri, A. M., \& Mukaram, M. (2018). Pengaruh ROA, ROE, dan NPM terhadap pertumbuhan laba pada perusahaan sektor industri barang konsumsi yang terdaftar di Bursa Efek Indonesia. Jurnal Riset Bisnis dan Investasi, 4(1), 25. https://doi.org/10.35697/jrbi.v4i1.990

Widiyanti, M. (2019). Pengaruh Net Profit Margin, Return on Assets dan Debt to Equity Ratio terhadap pertumbuhan laba pada perusahaan LQ-45. Jurnal Riset Akuntansi dan Keuangan, 7(3), 545-554. Diakses dari https://ejournal.upi.edu/index.php/JRAK/article/view/17826 